\title{
Unwilling Fathers and Abortion: Terminating Men's Child Support Obligations?
}

Sally Sheldon

Modern Law Review 66 (2) pp175 - 194

Post Refereed Version - Not Published Version

\begin{abstract}
There is broad agreement across the western industrialised world that men who father children outside of marriage share in an obligation to support their offspring financially. Against this consensus, some men's groups have claimed that if women are accorded control over the decision to continue or to terminate a pregnancy then it is unfair to hold genetic fathers financially liable for child support. This paper assesses the merits of this claim from a feminist perspective. Having considered a number of arguments, it suggests that the currently accepted grounding of child support liability (in voluntary creation of need) provides little scope for refuting the men's groups' argument. The paper then moves on to argue that voluntary creation of need is, however, inadequate as a basis for child support liability, and that the current analysis offers compelling grounds for preferring a collective model of support obligations.
\end{abstract}

Keywords: fathers, abortion, child support

\begin{abstract}
To saddle a man with at least eighteen years of expensive, exhausting child support liability on the basis of a haphazard vicissitude of life seems to shock the conscience and be arbitrary, capricious, and unreasonable, where childbirth results from the mother's free choice y a man no longer has any control over the course of a pregnancy he has biologically brought about [and] it is unjust to impose responsibility where there is no ability to exercise control. Although the father played an initial physical role in the creation of the fetus, he no longer has any control over the process which converts his biological act into personhood. The father's participation in the procreative process begins and ends with the sexual act; from the moment of conception on, all control and authority concerning the fate of the pregnancy rests with the mother. The father's role, in terms of decision making power, is reduced to impotent bystander y As the authority to cause a birth has shifted exclusively to the woman, so too should the responsibility flowing from the result of her unilateral exercise of that authority shift to her solely, away from the helpless third-party father.1
\end{abstract}

Introduction

There seems to be broad agreement in much of the western industrialised world that men who father children out of marriage share an obligation to support them financially. As one leading American family lawyer puts it:

1 M. B. Kapp, 'The Father's (Lack of ) Right and Responsibilities in the Abortion Decision: An Examination of the Legal-Ethical Implications' (1982) 9 Ohio NULR 370, 376-377. 
[t]he duty that parents have to support their children rests, in our culture, on the widely shared belief in each person's responsibility for his voluntary actions and in deeply rooted notions of what it means to be a parent. Conservatives feel additional anger when they, as taxpayers, are required to pay for children born of nonmarital relationships that they consider immoral. Liberals feel anger of another sort. They deplore the gendered nature of the problem. They know that it is men who walk away from their children, and women left in poverty who bear the burden.'2

Against this consensus, some commentators (who, for the purpose of this article, I will refer to as 'men's advocates') cry foul.3 They claim that if women have complete control over the decision to continue or to terminate a pregnancy then it is unfair to hold genetic fathers financially liable for child support.4 As a feminist, I have long assumed that all genetic fathers should share in the costs of raising a child for broadly the reasons which Chambers identifies above as 'liberal'. Women are clearly disproportionately burdened (in both financial and other ways) by the care of children and this is a significant part of any convincing explanation of the feminisation of poverty.5 This gross inequity would only be exacerbated by removing men's automatic liability for child support. Yet, on its own, I find this inadequate as a rebuttal of the claims of the men's advocates. Concerns about gender inequality alone cannot justify fixing financial duties towards genetic children onto particular individuals, in this case their unwilling genetic fathers.6 And the arguments which are typically made for fixing this obligation on these specific individuals are problematic to me precisely as a

2 D. L. Chambers, 'Fathers, the Welfare System and the Virtues and Perils of Child-Support Enforcement' (1995) 81 Va L Rev2575, 2588. Gwendolyn Mink detects the same consensus between conservatives, moderates, and liberals and many middle-class feminists, noting that 'across thirty years of welfare reform, the only true faith has been in the child support obligation of the absent father', see G. Mink, Welfare's End (Ithaca and London: Cornell University Press, 1998) 78.

3 The men's and fathers' rights movement is a disparate, complex and evolving body representing a variety of (sometimes conflicting) interests, see: A. Gavanas, 'The Fatherhood Responsibility Movement: the Centrality of Marriage, Work and Male Sexuality in Reconstructions of Masculinity and Fatherhood', in B. Hobson (ed), Making Men into Fathers: Men, Masculinities and the Social Politics of Fathers (Cambridge University Press, 2002), and W. F. Horn, D. Blankenhorn and M. B. Pearlstein, The Fatherhood Movement: A Call to Action (Lanham and Oxford: Lexington Books, 1999). I use 'men's advocates' as a convenient shorthand and do not mean to imply that all those who write on men's studies or masculinities, or even all of those involved in the men's and fathers' movement(s) would agree with the views advanced in this name. 4 That putative fathers have no legal right to prevent their sexual partners from terminating pregnancies has been established in the UK in the cases of Paton v BPAS [1979] QB 276, C v S [1988] QB 135, aff'd CA, and Kelly v Kelly [1997] 2 FLR 828; in the European Court of Human Rights (at least for early pregnancy) in Paton v UK (1980) 3 EHRR 408; in Canada in Murphy v Dodd (11 July 1989), Toronto 1566/89 (Ont S C) and Tremblay v Daigle [1989] S C R 530, 62 DLR (4th) 634; and the USA in Rothenberger v Doe (1977) 149 NJ Super 478; 374 A 2d 57; Coleman v Coleman (1984) $57 \mathrm{Md}$. App 755; 471 A 2d 1115. The unconstitutionality of spousal consent, veto or consultation provisions has also been established in the USA in Planned Parenthood of Central Missouri v Danforth, S Ct 1976) 428 US 52, 96 S Ct 2831 and Planned Parenthood v Casey (SCt 1992) 505 US 833, 112 S Ct 2791.

562 per cent of lone parent families (the vast majority of which are headed by women) were officially defined as living in poverty in 1998/9, compared to only 24 per cent of two parent families, see Department of Social Security Households Below Average Income: 1994/95-1998/9 (2000). By talking of 'burdens' here, I do not mean to suggest that raising children does not also bring benefits. Rather, following Martha Fineman, I am using 'burden' to signify 'that there are costs associated with what women typically do as caretakers in society. These labors may provide "joy," but they are also burdensome and have material costs and consequences. Not to recognize them as "burdens" is to ignore the costs to women and to continue to make women's labor invisible, as well as to condone that it is uncompensated.' M. Fineman, The Neutered Mother, the Sexual Family and Other Twentieth Century Tragedies (NY and London: Routledge, 1995) 162. 6 If our sole concern in imposing child support obligations on genetic fathers was to address gender inequality, then we would be far better off imposing a tax on all (childless) men. 
feminist. Notably, conservatives frequently claim that those who do not want to procreate should not have sex, or that those who fail to use contraception should 'face the consequences' of their 'reckless' behaviour. This argument is one which has historically been used to deny access to abortion services and that should at least give pause for thought before feminists or liberals choose to invoke it in this context.

This paper represents my attempt to think through the argument made by the men's advocates. It is intended to provoke discussion with other feminist and liberal thinkers who, I suggest, should be uneasy with relying on the conservative argument outlined above. Consequently, for the purposes of this paper, I will take as given firstly that allowing women to separate sex from procreation inter alia by way of liberal access to abortion is a good thing, and secondly that the abortion decision should belong to the pregnant woman. In the light of these assumptions, in what follows I will sketch the most sophisticated form of the men's advocates' argument before looking at some possible rebuttals which do not rely on the inseparability of sex and procreation. I will begin, though, by providing some background to this discussion through setting out the most commonly accepted ethical basis for child support obligations.

\section{The Obligation to Pay Child Support}

The duty of parents to provide for the maintenance of their children, is a principle of natural law; an obligation laid on them not only by nature itself, but by their own proper act, in bringing them into the world; for they would be in the highest manner injurious to their issue, if they only gave their children life, that they might afterwards see them perish. By begetting them, therefore, they have entered into a voluntary obligation, to endeavour, as far as in them lies, that the life which they have bestowed shall be supported and preserved. Thus the children will have a perfect right of receiving maintenance from their parents.7

To many, the assumption that genitors are obliged to provide for their children may seem so obvious as to be in need of no justification.8 It can be traced back to before Blackstone who located its roots in natural law and the parents' 'own proper act, in bringing [children] into the world'.9 Whilst most contemporary legal theorists reject natural law as a way of grounding obligations, the idea of voluntary creation of needs still seems the most plausible and commonly accepted explanation of genitors' liability for child support.10 According to this idea,

7 W. Blackstone, 1 Commentaries on the Laws of England (1765) $n 447$, at 247. Blackstone himself was relying on the authority of Puffendorf, Law of Nature and Nations (1688).

8 For example, in the US case of Doughty v Engler 112 Kan 583, 584, 211 P 619 (1923), the Court noted that the father's non statutory duty to support his illegitimate child has been 'accepted as a matter of course without the assignment of any reason.'

9 See note 7 above.

10 For reasons of space, other possible arguments are not dealt with here. The most convincing would see financial liability as operating either as a deterrent against the creation of children outside of a stable heterosexual quasi-marital unit, or as a punishment for having done so. But feminists have argued strenuously against the prohibition of abortion on the basis that continuation of pregnancy would punish or deter women from (irresponsible) sexual behaviour. While it is clearly possible to make a distinction here on the basis that forcing someone to continue a pregnancy is qualitatively different from forcing someone to pay child support, I would suggest that the better argument is that people should not be punished for extra-marital sex (or extra-marital creation of children) at all unless these activities can be correctly characterised as harmful. This is further explored below, see notes 50-55 and accompanying text. 
genitors' obligations are grounded in an idea of consent (either to procreation itself or to running a risk of it). But to what is a man deemed to have consented and when does this consent take place? Given that an unwilling father is by definition opposing the birth of the child, the argument must be that he was consenting to run the risk of pregnancy when he consented to engage in particular kinds of sexual activity. Thus, it is said, if men do not want to father children then they have a clear choice - not to engage in those activities liable to result in insemination:

few men ... can be forced to engage in intercourse without taking appropriate precautions. Therefore, a responsible man who willingly engages in an act with known possible consequences may fairly be held responsible for those consequences. If he is not willing to be held responsible, he should not commit the act in question ... The principal focus of a contract concept should not rest upon a man's liability for support but upon highlighting his responsibility for ensuring that conception not occur either by abstaining from intercourse or by taking necessary contraceptive precautions for his own protection.11

It is on precisely this point that the men's advocates have waged their attack.

\section{Abortion as Breaking the Causal Chain Between Sex and Procreation}

In its most sophisticated form, the claim made by some men's advocates is that safe, legal abortion has challenged the inevitability of the causal link between sex and procreation for women and, as such, it is unfair not to allow that this chain may also be broken for men in certain circumstances. This is well expressed by the two following commentators:

By legalizing abortion we gave women the right to say 'I know a child was conceived, but I refuse to accept the parental responsibilities because I can't afford the parenthood right now ... or because l'm not emotionally ready to handle them ... or, because I want to finish school or build a career first ... or, maybe I just want to use my money for a new car or spend the next nine months in Europe ... or frankly, it's none of your business. No one is going to give me parental responsibilities unless I choose to have them.... We are no longer being truthful when we chide the male defendant, "It took two to make the baby. It isn't fair for you to leave her stuck with the problem." It might have taken two to conceive the embryo, but thanks to legalized abortion, only one person controlled whether or not a baby was made. Today, the only women who become mothers are women who choose consciously and deliberately to become mothers.12

The traditional causal chain - intercourse, conception, birth - is seen to have a new link: the conscious decision of whether to abort, inserted between conception and birth. The conscious decision in the former chain, the assumed mutual decision of whether to have intercourse, and the risk of the consequence of conception and birth, are now superseded by a unilateral decision on the part of the mother. The man may publicly state his wishes that the woman abort and may even offer to pay for the procedure, but the decision is solely the woman's. Under

11 E. M. Young, 'Threshold Issues Associated with the Parental Obligation of Child Support' in J. Casserty (ed), The Parental Child-Support Obligation (Lexington Books: Lexington MA, 1983) 68. 12 F. Hayward, 'Abortion Rights for Men: Some Careful Thinking About Fathers' Rights' 20 Everyman: a Men's Journal 8 (31 August 1996) 8. 
current law if the decision is negative, the man is liable to support the child under the same conditions that any other child-support determination is made. Is this a fair and equitable situation for the man? ... By so unequivocally removing the man from the supposed causal relationship between the decision to abort and the birth of the child, it may be argued that his liability to support should take that fact into consideration. Specifically, the woman's decision not to abort when the man wishes otherwise should place the burden of support on the woman. The scientific possibility, medical safety and legal permissibility of abortion make this a tenable argument, assuming, of course, that the woman is free to choose because there are no medical, religious, or other uncontrollable obstacles to that choice.13 These authors have been joined by some feminists in expressing concern at the perceived disjuncture of men's rights and responsibilities in this context, a former president of the US National Organisation of Women noting that:

Justice ... dictates that if a woman makes a unilateral decision to bring [a] pregnancy to term, and the biological father does not, and cannot share in this decision, he should not be liable for 21 years of support. Or, put another way, autonomous women making independent decisions about their lives should not expect men to finance their choice.14

In other words, the state of affairs familiar to Blackstone where having sex could be understood as involving consent to run the risk of procreation no longer pertains. In agreeing to have sex, sexual partners do not necessarily agree to procreate: 15

Many believe that individuals' willingness to have heterosexual intercourse represents prima facie evidence of their willingness to accept the financial consequences associated with a pregnancy and possible birth. This traditional view of sexuality is inconsistent, though, with a progressive view of consensual sex as an opportunity for personal expression and development, independent of reproductive needs. Sex, seen in this contemporary light, does not excuse men and women from acting ethically. It merely implies that individuals who are capable of financially supporting their own children should be given the opportunity to make personal and informed decisions about how they wish to express their sexuality, while at the same time stipulating their preferences about parenthood.16

On this basis, some American commentators have suggested the need for new, consent-based, mechanisms for the attribution of paternal rights and obligations. In 1992, the US National Center for Men suggested that partners should be allowed to sign a 'Consensual Sex Contract' outlining terms under which they agree to have sex.17 More recently, sociologist William Marsiglio has made a

13 Young, note 11 above, 62-63. Young goes on to express reservations about this argument, citing economic disparity between men and women, the needs of children and a concern that they should not become the burden of the taxpayer. See also G. Swan, 'Abortion on Maternal Demand: Paternal Support Implications' (1975) 9(2) Val U L Rev243, 265, 266; Kapp, note 1 above. 14 Karen DeCrow, letter to the editor, New York Times Magazine (9 May 1982), cited in W. Marsiglio, Procreative Man (New York and London: New York University Press, 1998) 97. 15 This leaves open the question of whether they may be consenting to run the risk of pregnancy and therefore retain an obligation to share in the cost of terminating that pregnancy if it is unwanted. 16 Marsiglio, note 14 above, 182. Note that Marsiglio would limit this ability to opt out of child support liability to situations where the woman is capable of supporting a child without male assistance. In the light of Marsiglio's previous argument, this is a rather curious exception which allows the interests of the tax payer to trump those of the genetic father, without any supporting argument for why this should be so.

17 One clause reads: 'We're not ready to be parents now. If an unplanned pregnancy occurs, neither of us will try to force the other into parenthood', cited in ibid 98. 
similar argument for what he calls a Pregnancy Resolution/Child Support Contract.18 Taking the contractual model to greater lengths, one group of authors have even argued for a legal agreement which would allow a woman also to assign her right to decide whether or not to terminate a pregnancy to her sexual partner. 19 Others have argued that the male genitor should have the right to decide whether to recognise a child at some point after conception, thus mirroring the woman's right to decide whether or not she wishes to go ahead with pregnancy and to become a mother. If the man refuses to do so, it is claimed, he should acquire neither the rights nor the responsibilities associated with parenthood.20 In other words, given that safe legal abortion has made parenthood a choice for women, so too should it make it one for men.

\section{A Feminist Rebuttal?}

Have the men's advocates got a point? Of course, as noted above, some would argue that in agreeing to sex, men do agree to procreation and that it is immoral, irreligious or (in the rhetoric which tends to be more popular in contemporary times) 'irresponsible' to separate these two things. For such commentators, child support liability can serve to act as a punishment or deterrent for the unmarried, the promiscuous or the otherwise sexually feckless. This is an easy move for conservatives, who often aim to remove or to limit abortion rights on the same basis. However, these arguments are not ones which should appeal too readily to feminists (or to many liberals) who have fought too hard and too long against the operation of this assumption with regard to women, now to accept its operation with regard to men.21 Marsiglio is surely right in recognising that most commonly people have sex for reasons other than procreation and feminists have typically greeted legal recognition of this social fact as a good thing.

In what follows, I look at three other kinds of argument which may seem more appealing to feminist and liberal thinkers. The first focuses on the needs of the child, the second on challenging the idea that continuing a pregnancy represents a 'choice' for women, and the third explores whether abortion decisions are 'special' in a sense which means that they cannot play the role which the men's advocates suggest.

18 ibid 175-83.

19 P. Feaver, R. Kling and T. Plofchan, 'Sex as Contract: Abortion and Expanded Choice' (1992-3) Stan L \& Pol'y Rev211. For a robust rebuttal, see M. Fineman, 'A Legal (And Otherwise) Realist Response to "Sex as Contract"' 4(1) Col Jo Gender and Law 128.

20 This accords with a view of parenthood based on intention to parent. For an examination of this view see J. L. Hill, 'What does it mean to be a Parent?' (1991) 66 NYUL Rev 353-420; G.

Douglas, 'The Intention to be a Parent and the Making of Mothers' (1994) 57 MLR 636, commenting on the decision of the Californian Supreme Court in Johnson v Calvert (1993) $5 \mathrm{Cal}$ 4th 84. For the relevance of intention in grounding parental rights in the UK context, see further S. Sheldon, 'Unmarried Fathers and Parental Responsibility: a Case for Reform?' (2001) 9(2) FLS 93.

21 The similarity between the arguments used by the men's advocates and feminists defending abortion rights in this context is striking. For example, the US group Choice for Men respond to the question: 'Can't men avoid paying child support by just using condoms?' with an argument often made in defence of abortion rights: 'Proponents of legalizing choice for men generally support contraception, but keep in mind that condoms are unreliable. Condoms have a $16 \%$ annual failure rate. After just four years you can bet on having an accidental pregnancy and after 20 years of using condoms, the chances are that a man will most likely experience not one, not two, but three accidental pregnancies!' http://www.nas.com/c4m/faq.html (last visited, 23 April 2002). 


\section{The Needs of the Child}

Continuing a pregnancy will produce a child with a bundle of practical, emotional and financial needs. Legally, it is not open to genetic parents to bargain away the rights which will accrue to that child on birth and, regardless of what is said before a pregnancy is conceived, the child's right to support cannot be waived by its mother.22 While it is clearly right that the mother should not be able to sign away rights belonging the child, however what is lacking in this argument is some grounding for why the genetic father should have the responsibility for meeting the needs of his children in the first place. The very issue under discussion is whether there is any sustainable basis for the child to claim a right to support from its genetic father. What is it that grounds the right which cannot be waived? Surely it is not merely the genetic relationship - to note a genetic link is to state a biological fact, not to present an ethical justification.23 Nor can parental obligations be grounded in nothing more than factual causation, that is, in the idea that if you create a set of needs (here by bringing a child into the world) that you have a duty to meet those needs to the best of your ability. Factual causation does not fix legal or ethical duties without something more.24 Some further element is necessary and Blackstone's explanation of parental obligation does introduce such a further requirement - that the creation of needs is voluntary. But this brings us squarely back to the men's advocates' argument that, in cases where the genitor is unwilling to become a father, sex may have been voluntary but the creation of a child was not.

\section{Continuing a Pregnancy is not a 'Choice'}

A second possible strategy for rebutting the men's advocates' argument lies in attacking its premise that the availability of safe, legal abortion makes continuing a pregnancy a matter of 'choice' for women. If birth does not result from a voluntary choice, then their argument fails in two possible ways: first it cannot break the causal chain between sex and procreation (as the latter would then appear as an inevitable consequence of the former); and secondly, they have no way of distinguishing between the man's and woman's relationship to the child (ie

22 Child Support Act 1991, s9(3) makes it clear that child support obligations cannot be left to the free will of the parents: the fact of having entered into a maintenance agreement will not preclude a parent with care from applying for a maintenance assessment at some later date. This provision reflects the earlier decisions of Hulley v Thompson [1981] 1 WLR 159 and Crozier v Crozier [1994] 1 FLR 126, 135. Similarly, the US courts have held that personal agreements concerning contraception are not relevant to determinations of child support liability, which is based on the financial situation of the parents and the needs of the child. See in particular: Straub v BMT (1994) 645 NE 2d 597.

23 As a matter of social fact, a lot of genetic links do not give rise to social obligation. The closest genetic link you could have would be to your clone: would this of itself imply an obligation to support him or her? We do, as a matter of fact, often claim that people owe special obligations to different categories of genetic relation, but what the cloning example suggests is that our ethical intuitions about obligations are grounded not in the genetic fact alone but in the social and legal structure which has been built upon it.

24 In terms of factual causation, one is created not just by one's parents but also by all one's grandparents, great grandparents and beyond. Causation is an extremely complex concept which has generated a vast legal and philosophical literature, but my point here is hopefully an uncontroversial one: that while factual causation may be necessary to ground certain kinds of obligations to other people, it is never sufficient to do so. For an early and influential discussion of causation see: H. L.A. Hart and A. M. Honore', Causation in the Law (Oxford: Oxford University Press, 1959). 
if neither made a voluntary choice to procreate, then neither would be financially liable in child support on the basis of voluntary creation of need).

Do women exercise choice when continuing a pregnancy?25 Feminists have certainly relied heavily on claims to reproductive choice in campaigns around abortion. The 'Pro-Choice' movement has argued specifically to retain that name, with activists repeatedly pointing out that they are not 'pro-abortion' but aim only for appropriate support and facilitation of whatever decision a pregnant woman wishes to make. Feminists have criticised the Abortion Act 1967 for its representation of maternity as an unconsidered norm or default position, with abortion only available for those who somehow fail to conform to the model of the good mother.26 Far better, it has been argued, to emphasise pregnant women's capacity to make the best decisions about their pregnancies - whether that be to continue or to end them.27

At the same time, a major and recurring theme of feminist scholarship has been uneasiness with the idea of choice. This stems from a clear recognition of the role which claims of 'choice' have played in justifying women's continued subordination. For example, women's continued inferior position in the labour market has been explained as a result of individual women's choices to prioritise home and family.28 As such, it is important to recognise that decisions are never made in a vacuum. In making choices, we are all influenced both by the opportunities presented to us and the attitudes of those with whom we interact.29 Feminists have also expressed particular concern about the use of choice as a foundation for

25 An interesting example of judicial approval of the idea that continuing a pregnancy represents a positive choice is provided by the US case of Miller v Albright 523 US 420 (1998). Here the Supreme Court considered a provision granting automatic US citizenship to the child of a US unmarried mother and an alien father, whilst requiring affirmative steps to create or confirm the relationship where the child was born to a US unmarried father and alien mother. Refusing to strike down this distinction as an unconstitutional gender-based classification, the majority reasoned: '[i]f the citizen is the unmarried female, she must first choose to carry the pregnancy to term and reject the alternative of abortion - an alternative that is available by law to many, and in reality to most, women around the world y [The law] rewards that choice and that labor by conferring citizenship on her child' (per Justice Stevens at 420). For the majority of the Court, the continuance of pregnancy is a positive and conscious choice implying a recognition of, and commitment to, the eventual child.

26 For example, M. Boyle, Rethinking Abortion (London: Routledge, 1997); S. Sheldon, "Who is the Mother to Make the Judgement?": the Construction of Woman in English Abortion Law' (1993) 1 FLS 3; and S. Sheldon, Beyond Control: Medical Power and Abortion Law (London: Pluto, 1997).

27 See for example, S. Sheldon (1993) ibid, particularly at 22. Note that my claim here was explicitly a strategic one - to construct an image of the rational, self-determining, responsible and mature pregnant woman who can best serve the needs of the 'concrete women who stand behind her'. 28 'The old notion that women are not intelligent enough or lack the moral accountability to be leaders in business, politics, or the academy has been replaced by justifications centered on women's choice. This explanation of women's disadvantage is particularly prominent in the discourse on women in the workplace. The conventional wisdom is that because women place more importance on their families, they voluntarily choose to subordinate their career and job aspirations for the sake of their children or their partners. This rationale allows employers to make the paradoxical claim that women actually prefer lower-paying jobs or jobs that offer little opportunity for advancement.' M. Chamallas, An Introduction to Feminist Legal Theory (Gaithensburg and New York: Aspen, 1999) 20.

29 ibid 21. See also V. Shultz, 'Telling Stories about Women and Work: Judicial Interpretation of Sex Segregation in the Workplace in Title VII Cases Raising the Lack of Interest Argument' (1990) 103 Harvard L Rev. 1749; J. Williams, 'Deconstructing Gender' (1989) 87 Mich L Rev797, 830: discussing the 'extent to which women use [women's culture] against themselves, as they do every time a woman "chooses" to subordinate her career "for the good of her family" and congratulates herself on that choice as a mature assessment of her own "priorities"'; and J. Williams, "Gender Wars: Selfless Women in the Republic of Choice' (1991) 66 NYUL Rev1559 1617: 'the rhetoric of choice veils the extent to which entitlement to self development is gendered in contemporary American life'. 
abortion rights worrying that, in a consumerist society, 'choice' now is understood as 'referring to a selection between more than one ideal in an effort to fulfil wants, wishes or desires' and thus provides a skewed and inaccurate representation of women's experience of abortion decisions. 30 In the context of reproduction, Jo Bridgeman has argued that:

Neither the unpleasant side effects nor risks to health of contraception, the lack of social provision to assist in the cost of bringing up a child which forces a woman to choose to abort, nor the physical and emotional pain of high-tech, low-success fertility treatments are acknowledged. The focus upon choice masks the circumstances in which women make decisions about pregnancy and childbirth.31

In the context of pregnancy decisions, the circumstances to which Bridgeman might wish to direct our attention are well known. Putting to one side the case of Northern Ireland,32 while access to abortion services is relatively liberal in the UK, well entrenched obstacles to reproductive choice nonetheless still exist - most seriously for young women, women living in remote areas and ethnic minority women.33 The fact that the medical profession are gatekeepers to termination services enhances doctors' control over abortion decisions.34 Other powerful determining factors will include the woman's economic situation, the difficulties of combining family and work lives, and the views of her church, community, friends and family. Most poignantly, reports of women and girls who conceal their pregnancies and abandon their newborn babies are a regular, if not common, news item. One assumes that these women did not feel that continuing their pregnancies was a 'choice' nor that it was possible to 'decide' on termination. In other words, the feminist demand for 'reproductive choice' remains an aspiration rather than a reality. And it can only ever remain a partial description of women's experience of abortion. As Fox points out:

Even where a woman does have access to abortion, characterizing her action as one of choosing fails to capture the complexity and ambivalence of women's responses to the experience of abortion. The slogan "a woman's right to choose" risks masking women's

30 J. Bridgeman, 'A Woman's Right to Choose?' in E. Lee (ed), Abortion Law and Politics Today (London: Macmillan, 1998) 86. Marie Fox notes that 'tt]he rhetoric of choice also stems from liberal imagery of autonomous individuals making choices in their own self(ish) interest(s) and thus facilitates the characterization of the woman who seeks abortion as selfish.' M. Fox, 'A Woman's Right to Choose? A Feminist Critique' in J. Harris and S. Holm (eds), The Future of Human Reproduction (Oxford: Oxford University Press, 1998) 81-2. Kathryn Abrams notes an interesting reluctance on the part of (US) feminists to engage in a strong critique of choice in this area. She offers one possible, speculative explanation for this: that given women's right to choose is already under attack, to question the way in which women choose or to impugn their capacities as rational decision makers might appear reckless. See K. Abrams, 'Ideology and Women's Choices' (1989-90) 24 Ga L Rev761-801, at 786.

31 ibid 86.

32 See Fox's powerful critique of the use of 'choice' to describe women's experience of abortion services in Northern Ireland, note 30 above 83-84. In a context where abortion services are so restricted, it would clearly be difficult for the men's advocates to establish the first premise of their argument: that women have control of abortion decisions.

33 See S. Sheldon, 'The Abortion Act 1967: a Critical Perspective' in E. Lee (ed), Abortion Law and Politics Today (London: Macmillan, 1998) 54 . This observation relies on the fact that minority and younger women are less likely to know their way around the health system and may be more surely deterred by an unsympathetic reception from their GP. Women who live in rural areas will usually only have access to one GP's surgery and if that GP is hostile to abortion, then their situation is also particularly difficult. See also Fox note 30 above 82-88.

34 S. Sheldon (1997), note 26 above, especially chapter 4. 
problems with abortion - in particular the fact that abortion is not a complete solution to the problem of unwanted pregnancy. 35

However, while Fox and Bridgeman both produce powerful and convincing critiques of the 'right to choose' as a basis for feminist campaigning in this area, their analysis does not deny that many of the women who will terminate pregnancies in Britain this year (and the many more who will continue them) will exercise careful, thoughtful choices. These are women with alternatives (though typically none of them ideal) which are often considered and discussed at length, sometimes in extremely supportive, explicitly pro-choice environments. 36 These women will deploy 'complex moral reasoning'.37 They may feel deeply ambivalent about their decisions and they will invariably feel constrained by a range of external influences, but so too are there influences on any significant decision which any of us ever make. The existence of these constraints does not render a decision invalid. So while it is right to feel concern with the role of choice in the men's advocates' argument, I do not think it is tenable to claim that the majority of women do not exercise choice in continuing a pregnancy.

\section{Pregnancy/Abortion Choices are 'Special'}

Alternatively, might it be possible to accept that continuing a pregnancy is a choice, but to argue that it is qualitatively different from other choices in a significant sense (ie in a sense which means it cannot play the role which the men's advocates suggest)? I think not, though I will briefly canvass four arguments which might be made in this regard.

First, might it be argued that motherhood responds to a deep-rooted need or a 'natural' course of events rather than a choice? On this view, while women may sometimes decide to end a pregnancy, continuing a pregnancy does not involve choosing but merely allowing nature to run its course. Abortion appears as an exception to the norm of maternity. But the appeal to biology or 'natural course of events' in this argument is clearly problematic for feminists, who have worked hard precisely to establish that motherhood is not the natural or 'default' option for women but one possibility amongst others. Feminists have criticised in the strongest of terms those stereotypes relied on by doctors who advise women to go ahead with pregnancies because their 'maternal instincts will inevitably take over', and politicians who have opposed abortion rights on the grounds that 'deep down' all women want to have children. Moreover, the want or need to have a child at some point in one's life clearly does not dictate one's attitude to a given pregnancy. Women frequently choose to terminate pregnancies because they have occurred at the wrong time or with the wrong partner and then go on to have children at some later date.

35 See note 30 above 84 .

36 The charitable clinics, of which the British Pregnancy Advisory Service is the largest service provider, were set up explicitly to provide terminations in a supportive and non-judgmental environment. There is considerable evidence to suggest that they are staffed primarily by individuals who would identify as strongly pro-choice and strongly pro-women (see M. Lattimer, Abortion Discourses: an Exploration of the Social, Cultural and Organisational Context of Abortion Decision-Making in Contemporary Britain, unpublished PhD thesis, University of Sussex, 2000). 37 Fox, note 30 above 99. 
Secondly, is the decision to continue a pregnancy significantly different because reproduction is a fundamental human right? The right to found a family is certainly a staple ingredient of human rights treaties and is commonly interpreted to include reproductive rights. But the received interpretation of a right to reproduce has been as a negative right, a right that others should not seek to prevent us from pursuing our own reproductive goals, for example, by forced termination or compulsory sterilisation. We do not generally believe that someone else has a duty to supply women with sperm or sexual partners so that we can realise our right to reproduce. Nor do we believe that a man has the right to force a woman to continue with an unwanted pregnancy so that he can achieve his dream of becoming a father. Should we then believe that male partners have a duty to finance a woman's fundamental right to reproduce? I would argue that to continue a pregnancy should surely be accepted as a human right in the sense of implying important negative duties of non-interference, but that the right to continue a pregnancy is not typically understood as a human right giving rise to positive duties on the part of other individuals. 38

Thirdly, the men's advocates might be attacked for assuming that men's and women's relationships to reproduction are equivalent, when clearly they are not.39 At the heart of the men's advocates' argument lies the claim that since parenthood is now a choice for women, so too should it be a choice for men. Yet whilst men and women may share the same genetic interests in procreation, there is clearly no male equivalent for women's interest in gestation. It is this fundamental asymmetry in the nature of reproduction which is often taken as grounding women's rights to choose to terminate (or to continue) a pregnancy in the face of male opposition: since a pregnancy is occurring within the woman's body, that woman has a special claim to control its outcome. The legal significance of this gestational interest can clearly be seen in a comparison of the law dealing with the disposal of frozen embryos and access to abortion respectively.40 As in the UK, the American courts have guarded women's right to decide on the outcome of a pregnancy against the claims of their male partners. However, where the issue is one of disposition of embryos existing outside the woman's body, the US courts have deemed the man's interest in avoiding procreation to outweigh the woman's interest in reproduction. 41 So while an asymmetry based on the woman's gestational labour can be advanced as a powerful argument in support of women's

38 Though it may be taken to imply certain duties on the part of the state: eg to provide adequate medical services, provision for maternity leave and so on.

39 I am grateful to one of the MLR's anonymous referees for this argument.

40 See Davis v Davis (1992) 842 SW 2d 588. 'If no prior agreement [regarding disposition of the embryos] exists, then the relative interests of the parties in using or not using the preembryos must be weighed. Ordinarily, the party wishing to avoid procreation should prevail, assuming that the other party has a reasonable possibility of achieving parenthood by means other than use of the preembryos in question.' See note 4 above for the actions brought by men attempting to prevent (former) partners from terminating pregnancies.

41 Provided that the woman has a reasonable possibility of achieving parenthood by other means. In Davis, Mrs Davis was intending to donate the embryos to another woman and therefore was not asserting an interest in achieving parenthood for herself, ibid. The same point may soon be tested in the UK. A woman who lost her ovaries to cancer has announced her intention to go to court to stop frozen embryos created from gametes taken from her and her former partner from being destroyed on his request. Her chances of success are negligible. As a spokeswoman from the Human Fertilisation and Embryology Authority correctly noted: '[f]or an embryo to be used in a treatment cycle both partners who created the embryo must consent to treatment and storage. So if the man does not consent to treatment, the treatment can't take place. There is no room for negotiation under the law.' See The Guardian, 3 August 2002, and the Human Fertilisation and Embryology Act 1990, Sched 3, s 4 which provides for variation and withdrawal of consent to the use of stored embryos. 
rights to control the outcome of a pregnancy, it is not clear how this would serve to ground the child support obligations of individual male genitors.42 Indeed, the men's advocates might claim here that they do recognise the asymmetry in men's and women's relationships to procreation (in recognising women's abortion rights), but are merely calling for a corresponding asymmetry in men's and women's obligations to resulting children.

Fourthly and finally, there will obviously be some situations where women can argue with considerable force that, notwithstanding the legality of abortion, the choice to end a pregnancy is not open to them. Most obviously, some women have strong moral or religious views which militate against abortion. A strict Catholic who sincerely believes that termination is morally equivalent to murder might argue that she does not have the choice to end her pregnancy. But there are two problems with this argument. First, the claim that choices should not count as such when they are based on one's most strongly held fundamental religious and moral views has important counter-intuitive results. 43 For example, if people marry then this would not count as a choice where they desire matrimony on the basis of deeply held religious convictions but it would count as a choice where their decision is motivated by a desire to improve their tax situation.44 Secondly, this argument also raises the issue of whether an individual's moral or religious belief should be allowed to impact on other parties in harmful ways. As one men's advocate notes:

some pregnant women feel compelled to bear unwanted children because they believe abortion to be murder. Nevertheless, the power to make that choice is one more power that women take for granted and most men dare not imagine. Thousands of men who also believe that abortion is murder have had to stand by helplessly and, from their perspective, watch their children be murdered. They only wish that they had an equivalent legal right to protect the lives of their own unborn children, whether the conception was planned or not.45

No woman should be forced to have a termination against her will whether her desire to continue a pregnancy is motivated by religious beliefs or not. The argument here, though, would require that one's religious belief could be advanced against an unwilling putative father as a justification for grounding substantial financial liability on his part, and this seems unconvincing.

Where does this leave us? To argue that women do not exercise a choice when continuing with a pregnancy risks denying women's agency and reinforcing negative stereotypes of maternity as the female norm with abortion justified only by exceptional circumstances. Feminists, in particular, have argued that pregnant women are the best abortion decision-makers, that women have the moral

42 Take a different example. Imagine that ova removed consensually from Anne are implanted into Brinda. We would probably think (and the law would suggest) that Anne has no right to demand that Brinda should terminate the pregnancy. However, we would also probably think (and again the law would concur) that the existence of a genetic link between Anne and the eventual child should not per se ground any obligation on Anne's part to support it. Rather, in determining the existence of such moral obligations on Anne's part, we might want to examine the circumstances of conception more closely, and possibly to draw a distinction between a situation where Anne and Brinda are partners who have together requested this procedure in order to bear a child who has a biological relationship to both of them, and a second scenario where Brinda has acquired the ova without Anne's knowledge. My point is that whilst Anne and Brinda's interests in the pregnancy cannot be treated as equivalent, merely this observation combined with knowledge of a genetic link between Anne and the child cannot per se ground any moral support obligation on Anne's part.

43 I thank Stephen Wilkinson for this argument.

44 Here I leave open the issue of to what extent moral and religious beliefs should in any case be understood as the result of choice.

45 See note 12 above. 
integrity necessary to make our own reproductive decisions, and that choosing to continue or to end a pregnancy are equally valid decisions. On the other hand, to argue that women are strong and capable decision-makers who are able to deploy 'complex moral reasoning' in determining our own best interests and those of our potential children seems to allow no basis for refuting the men's advocates' argument. The currently accepted grounding of child support liability in voluntary creation of need suggests no possibility for opposing the view that mothers should be solely financially liable for children where their sexual partners are unwilling to become fathers.

\section{Rethinking the Basis for Support Obligations}

If the analysis above is right, then it seems that the received basis for child support liability (voluntary creation of need) may suggest only holding so liable those fathers who are willing to be recognised as such. This is clearly a worrying conclusion. As noted above, female headed households are already clearly the poorest in the UK, with a substantial proportion of them already living in poverty. 46 Limiting men's obligation to provide financial support for their genetic children can only exacerbate already marked gendered disparities in wealth. 47 Yet without an ethical basis for holding unwilling fathers privately liable to support their children, there is nothing to justify sacrificing the interests of these particular men in order to allay our rightful concern on the issue of child and female poverty. However our analysis cannot stop here and, in what follows, I seek to extend it in a number of ways. Firstly, I assess the implications of the above argument and find that they are more far reaching than they might at first appear, extending well beyond the non-resident fathers who are typically targeted as problematic in discussions of child support. It is my contention that these consequences are so profound and so damaging when followed through to their inevitable conclusions that they provide new impetus for questioning the attempt to provide for children's basic needs through private support obligations. Secondly and more generally, I argue that voluntary creation of need is in any case highly problematic and should, at least, be extremely controversial as an ethical basis for grounding the support obligations of any parent. Thirdly, and briefly, I move on to assess what new light the analysis of this paper may shed on a very old debate: whether child support is best understood as a private or a collective obligation.

\section{Unwilling Fathers' (Lack of ) Support Obligations: Some Practical Consequences}

I have argued above that unwilling fathers are not captured by the received basis for private support obligations: voluntary creation of need. To assess the implications of this claim obviously requires consideration of who would count as an 'unwilling' father. Bearing in mind my starting premise - that we need to separate consent to sex from consent to procreation - then unwilling fathers are

46 See note 5 above.

47 Although such exacerbation may be more due to alleviating male poverty than to increasing that of women: much of what is paid in child support goes to the Treasury rather than to mothers, whilst many men are made poorer by virtue of paying child support. See further below. 
those who (regardless of whether or not they consented to sex) did not voluntarily create a particular child. In other words, for our purposes, unwilling fathers are those who did not choose for a particular pregnancy to continue. In practical terms, this would suggest the need for some formal process of recognition of paternity.48 In cases where no formal process of recognition has been completed, it would have to be assumed that men had not decided to create a child. 49 Would it make any difference that a man had already evidenced some long-term commitment to a particular woman by virtue of, say, cohabitation, joint purchase of a home or marriage? I would say not. Cohabitation and marriage are entered into for any number of reasons and, whilst a commitment to have and to raise children may be among these, it cannot be assumed to be a motivating factor for most people. Every man, then, would need to make some positive act of recognition to trigger his support obligations. Thus, whilst the analysis above has focussed on a particular group of men who have been most loudly proclaimed as faring badly in the context of the current system, the ambit of the argument inevitably extends far beyond them.

At this point, a number of practical outcomes should become clear. First, distinguishing between willing and unwilling fathers (as I have argued is necessary if we are to make sense of grounding support obligations on voluntary creation of need) would provide a powerful financial incentive for men to disown their biological children in order to avoid onerous support liability. In cases where child support obligations would then pass to the taxpayer, there would often be an incentive for women to collude in this process (perhaps on the promise of the informal provision of extra financial or other forms of support from the father). Secondly, where a woman is reluctant to reveal the existence of a pregnancy to a sexual partner, she would prevent the crystallisation of the child's right to recoup support payments. Thirdly, there would be considerable scope for putative fathers to apply extreme pressure on pregnant women at what is a peculiarly vulnerable time, using recognition of the eventual child as a bargaining chip. That some women would be pressurised into terminating pregnancies is inevitable. Finally, the fact that many more men would find themselves free from child support liability could only exacerbate the existing disparity of wealth between men and women and, given that children usually live with their mothers and are dependent on their mother's standard of living, then child welfare is likely to suffer.

As such, carrying the analysis of the first half of this paper through to its logical conclusion would clearly result in what most people would see as strongly negative consequences and fly against many popular social policy aims. Men would be encouraged to become less involved in their families; abortion of potentially wanted children would be encouraged; gendered disparities in wealth would be further entrenched; and child poverty would be exacerbated. Do these negative outcomes reveal a flaw in the analysis of the first part of this paper? Surely not. The problem which I have outlined above remains - if there is no sustainable ethical grounding for fixing liability for child support on unwilling fathers, then such a grounding cannot be found in noting the exacerbation of the general social problems set out above. Without more, the general desire to tackle a given social problem does not provide any ethical justification for why responsibility for

48 See the suggestions made by the commentators at notes 17-18 above and accompanying text. 49 This fits with the idea that the recognition must be 'voluntary'. For the assumption to operate the other way would be unworkable, not least because it would only make sense when combined with a positive obligation on women to inform a man of the existence of a pregnancy. Of course, this leaves open the possibility of a later act of recognition. 
addressing it should fall on particular individuals, rather than other people, the state, the general population as a whole or no one at all.

\section{More General Problems with 'Voluntary Creation of Need' as a Basis for Child Support Obligations}

Over and above these concerns, it seems that there are two more general problems with grounding child support obligations in voluntary creation of need which should lead liberals and feminists to treat it with extreme caution. These problems exist with regard not just to unwilling fathers, but with regard to all parents. Firstly, it must be noted that voluntary creation of need does not always lead to financial responsibility. If I am a Good Samaritan who saves a drowning child, or a skilled doctor who prolongs the life of one of my patients into a happily extended old age, have I created those individuals' future needs? In a factually causal sense, surely I have: my actions were essential to ensuring their (continued) existence. But for my intervention, they would be dead. Should I then be obliged to meet (part of ) the costs of their care? Presumably we would want to say not. What these examples suggest is that voluntary creation of need is only convincing as a basis for financial liability when such need results from harm to third parties.50 And if so, it is, at the very least, controversial as a basis for liability in this context. As a general rule, the birth of a child is not believed to be harmful either to the child itself or to its parents.51 Is it harmful to society? This question takes us straight to the heart of a familiar debate between liberal and conservative commentators, as the latter do often protest that the births of certain children (typically those born to 'non-traditional' family forms, or heterosexual couples who are unmarried or financially unable to support them) are a profound social harm. For example, the conservative US commentator, Charles Murray has argued that '[i]llegitmacy is the single most important social problem of our time more important than crime, drugs, poverty, illiteracy, welfare or homelessness because it drives everything else'.52 But progressive commentators in general, and feminists in particular, have tended strenuously to oppose this argument. Whether higher delinquency rates, drug use and educational under-achievement are the result of living in a single parent family or the result of the economic hardship experienced by most such families, remains a hotly contested

50 This seems to be accepted by Blackstone who notes that 'it would be in the highest manner injurious to their issue, if [parents] gave their children life, that they might otherwise see them perish', note 7 above. To be clear: my point here is that creation of harm (as opposed to mere need) is a necessary condition of moral and legal obligation, not that it is a sufficient one. The police surely harm the felon who is convicted and consequently loses her job as a result of their detection work, but provided that they have carried out their functions in an appropriate and lawful manner, they owe neither legal nor ethical duties to make reparation.

51 Along with most Western jurisdictions, the English courts have refused to recognise an action in wrongful life and have recently restricted the action for wrongful birth, limiting damages payable on the birth of a healthy child to pain and suffering during pregnancy, see respectively McKay $v$ Essex Area Health Authority [1982] QB 1166 and McFarlane and Another v Tayside Health Board [2000] 2 AC 59. Parkinson v St James and Seacroft University Hospital NHS Trust [2001] 3 WLR 376 and Rees v Darlington Memorial Hospital NHS Trust [2002] 2 All ER 177 (CA) establish limited exceptions to this rule in the context of the wrongful birth action where either the child or the mother is disabled. Some commentators argue that it is better for a child to be born in the context of a nuclear family but this clearly does not establish that a given child is harmed by its own birth (as the alternative to this birth is not birth into a different family environment but nonexistence). 52 C. Murray, 'The Coming White Underclass' Wall Street Journal, October 1993. 
issue.53 Moreover, feminist writers have argued that even if the birth of children can impose certain financial costs which individual parents will be unable to meet, children represent not just costs and needs but also the future wealth and continuation of society.54 In other words, the newborn babies of today (whether they be born to married parents or not) are the plumbers, nurses and refuse collectors of tomorrow. If parents derive a benefit from children, so too will society as a whole. This is true if we accept either a general societal interest in the continuation of the species, or our own individual interests as the dependent elderly of the future who will need a younger generation to care for us.55 The accuracy of conceptualising the birth of children as a 'harm', therefore, is far from established.

Secondly, it should likewise be recognised that our current practices are importantly inconsistent regarding the relevance of voluntary creation of need for support obligations. Adults in need of financial support were once just as surely and just as voluntarily created by their parents. However, we do not legally oblige parents to carry on supporting their offspring who have attained the age of majority and who have left full time education.56 Historically, when minors were seen as the property of their parents a distinction between adult and minor children made some sense. Today we have rejected the idea that parents 'own' their children and enjoy complete and unfettered rights over them, 57 in favour of understanding children as citizens (albeit citizens with particular vulnerabilities and needs). To a greater or lesser extent, western democracies have recognised a state interest in protecting and nurturing children. This interest has been used to justify intervention to protect children from neglectful or abusive parents, to demand that children are adequately educated, and to ensure that they receive necessary medical treatment. These measures are all based on the belief that children are individual members of society with independent rights. If we see dependent adults as the responsibility of society, why then do we assume dependent children are the responsibility of their parents? Voluntary creation of need does not help us here.58

53 S. McLanahan and G. Sandefur, Growing up with a Single Parent: What Hurts, What Helps (Cambridge MA: Harvard University Press, 1994).

54 See in particular Fineman, note 5 above.

55 Here it could be countered that while the birth of some children is good for society, current birth rates may be producing more future citizens than we (current citizens with projected needs) actually require. Remaining agnostic on the empirical question, if it is accepted that a certain level of reproduction is socially necessary I would suggest that, even if current birth rates are deemed too high, there are good other reasons (notably concerns for procreative autonomy) not to allow the state to regulate who may reproduce.

56 See N. Wikely, 'Children and Social Security Law' in J. Fionda (ed), Legal Concepts of Childhood (Oxford: Hart Publishing, 2001) for an overview of the position of children within the social security system highlighting the 'paradoxes and conflicts in the law's treatment of children and young people as nascent full members of the community', 223.

57 J. Montgomery, 'Children as Property?' (1998) 51 MLR 323.

58 Neither does the claim that a child is merely a life-style choice which therefore remains its parents' private financial responsibility, as would a new car or expensive holiday. Fineman refers to the idea that children are like any other consumer item as the 'Porsche preference': M. Fineman, 'Cracking the Foundational Myths: Independence, Autonomy and Self-Sufficiency' (2000) 8 Am $U$ Jo Gender, Soc Pol'y and L 13, 21. 'This [quasi-economic] argument states that if someone prefers a child, this preference should not be treated differently than any other choice (like the choice to own a Porsche). Society should not subsidize either preference. I hope the societypreserving nature of children helps to distinguish that preference from the whim of the auto-fan.' 


\section{Private or Collective Responsibility for Meeting Children's Needs?}

Whether children are (primarily) a collective or individual responsibility is an old debate which has generated a large literature too vast to discuss here.59 Without aspiring to resolve this issue, I do believe that the analysis of this paper has something new to offer our thinking on it. This contribution lies in challenging the common assumption that it makes sense to talk about parents in general, and nonresident fathers in particular, owing moral support obligations towards their children. The analysis above has shown that, for those who are not happy to rely on a conservative vision of sex (where consenting to sex also inevitably entails consenting to procreation), the received justification for private child support obligations must fail. If this moral obligation cannot be assumed then this creates serious problems for those feminists and liberals who argue for a model of support liability which is rooted in private responsibility. In the light of the above analysis, the frequently voiced question of 'why should I take responsibility for other people's children when the father is in a position to support them?' simply makes no sense. If there is no ethical grounding for individual paternal responsibility for many children then anger against 'absent fathers' who 'offload' their responsibility onto taxpayers is ungrounded - there is no parental obligation to be thus evaded. This leaves the feminist or liberal unable to locate a solution to the problem of the poverty of children and mothers within a privatised model of support obligations. Two final points of precision are necessary before I conclude. First, whilst arguing against the assumption that children's basic needs can be seen as a private obligation, I have said nothing about the many extras which parents often choose to provide for their children such as designer clothes, riding lessons, private education, or expensive holidays abroad. Should the cost of these items now also fall to the taxpayer? Whilst private models of child support have tended to reflect the parents' income on the grounds that children have a right to share in their parents' standard of living, it seems to me that this is a clearly inappropriate model to use for public support obligations for two reasons. First, such a model would serve to redistribute income towards the richest households: children in wealthier families might claim an expectation to attend expensive public schools and private hospitals while children in the poorest families clearly could not. Secondly, such a model remains premised on the nuclear family (where children share in the wealth of two genetic parents). This can no longer be taken as representative of the diversity of family arrangements in existence and, in any case, has no defensible role in the allocation of state benefits. I see no justification for suggesting that a child born following its mother's liaison with a wealthy oil tycoon should be able to claim more in support payments from the state than a second child conceived during her liaison with the tycoon's poorly paid gardener.60

Secondly, my contention that the state's responsibilities should be set at the level of provision of the child's basic needs leaves open the question of whether children

59 See R. Lister, 'Child Support: Boundaries of Responsibility' (1984) 11 Benefits Sept/Oct 1 and J. Lewis (ed), Lone Mothers in European Welfare Regimes (London: Jessica Kingsley, 1997) for a useful overview of the different models currently in operation. Lister identifies two basic models which she describes as the Anglo-American model (where market driven public policies have depressed family benefits and placed child-rearing firmly in the private domain) and a European model (where governments have strengthened safety nets for families with children).

60 This accords with the argument made above regarding the inconsistency of our treatment of children and dependent adults. The state's responsibility towards the latter requires meeting basic needs, not the provision of luxuries. If someone else, however, chooses to buy a holiday or expensive clothes for a less wealthy friend, then this is strictly her own concern. 
should also acquire additional enforceable rights against their parents for a higher level of private support. Although I do not have the space fully to explore this point here, it seems to me that there may be an argument for allowing such rights to additional support to be acquired either by virtue of a positive act of recognition or, in some limited circumstances, on the basis of the parent's actions. For example, imagine a case where a father pays for his children to enter an expensive public school but attempts to stop paying the fees on divorcing the children's mother. One might argue here that, regardless of whether the father has formally recognised a support obligation towards his children, he has acquired an obligation to pay these fees by his virtue of his children's legitimate expectation that he would continue to meet an expense that he had voluntarily assumed. It could be harmful to the children, and certainly not consistent with their best interests, to be withdrawn from a school where they were succeeding well or to be forced to take a drastic cut in living where continued maintenance lies within the means of the father. Full consideration of the possibility of grounding obligations in such a way, however, must remain the concern of another paper.

\section{Conclusions}

The beggarly question of parentage - what is it after all? What does it matter, when you come to think of it, whether a child is yours by blood or not? All of the little ones of our time are collectively the children of us adults of the time, and entitled to our general care.61

This paper has attempted a feminist analysis of the claim that it is unfair to hold men financially liable for their genetic children when they have no legal right to participate in abortion decisions. Staying within the confines of the privatised model of child support (with its premise that children are the financial responsibility of individual genetic parents on the basis of voluntary creation of need), I failed to uncover a convincing basis for imposing support obligations on unwilling fathers. Thinking more generally, I argued that voluntary creation of need cannot offer feminists and liberals a workable basis for thinking about support obligations. To make this argument, I first fleshed out the practical implications of the current analysis for a system of child support grounded in this way, before moving on to expose voluntary creation of need to a more general principled critique.

Returning to my starting point, the question of how to respond to the men's advocates' argument remains. Within the framework of privatised support obligations, I have found their argument to be more convincing than most have previously allowed. It has been my contention, however, that our inquiry cannot stop with this observation and that the ethical indefensibility of voluntary creation of need as a basis for support obligations should be understood as a reason for rejecting the private model of support obligations for meeting children's basic needs in favour of a stronger emphasis on collective responsibilities. It is my contention, then, that the state has a 
duty to meet children's basic needs and that this should be done at a generous level.62 The payment should be non-means tested and should be made on the basis that children are individual citizens with the entitlement of citizens to social support at times of incapacity (here by reason of immaturity) to support themselves.

There are other good reasons for supporting this view. Currently, across the western world, primary responsibility for childcare is assumed by women. When a privatised model of child support liability is combined with a clearly gendered structure of primary responsibility for children then it can be no surprise when female poverty results. And when this state of affairs is further exacerbated by the other factors which contribute to the feminisation of poverty (such as discrimination in the workplace and gendered educational and career expectations), then it is entirely predictable that child welfare will suffer. Leaving children dependent on the economic means of their parents has contributed significantly to the widespread poverty of women and children and, in countries where the wealth to rectify this situation exists, this should be cause for national shame.63 Moreover, attempting to address the poverty of women and children by entrenching their reliance on a male provider is problematic in societies where ever larger numbers of families do not conform to the nuclear family norm. Further, it relies on the identification of single motherhood as a form of deviance, in need of correction by binding women and children to a male breadwinner, 64 with the legally coerced (re)establishment of paternal presence, 'physically outside yet metaphysically completing, the family structure'.65 This is a clear attempt to enforce one view of the 'good life' on those who choose to live according to other visions and serves as a final and compelling reason for feminists and liberals to reject the model of privatised support obligations.

In the UK, whilst the Child Support Agency has been subject to vociferous criticism, this has tended to focus on detailing its 'catastrophic administrative failure'.66 Specifically its inefficiency in collection of support payments, unfairness in the method of calculating the level of support owed, and clear prioritisation of reducing public expenditure by recouping money paid out in welfare benefits have

62 While this may sound utopian, a non-means tested payment made automatically to every child (via his or her carer) would save large amounts of money currently spent on administering the current system of child support, which has been widely pilloried for its cost and inefficiency. At the end of 1996, the Social Security Select Committee reported that the cumulative savings achieved by the Child Support Agency in terms of social security expenditure amounted to d1.74 billion whilst the administrative costs of the Agency came to d660 million in its first four years of operation: G. Davis, N. Wikely and R. Young with J. Barron and J. Bedward, Child Support in Action (Oxford: Hart Publishing, 1998) 213, see also note 67 below. Obviously any administrative savings would not fully meet the greater cost of the proposed system, but my point is precisely to argue that the costs of child care should be redistributed from genetic parents to tax payers. 63 Leaving children so dependent also stands as a major obstacle to the Labour Government's 'historic aim' to end child poverty forever within a generation. See Tony Blair's 'Beveridge Lecture', Toynbee Hall, London, 18 March 1999, cited in N. Wikely, note 56 above, 241. 64 See generally: M. Fineman, note 5 above; C. Smart, The Ties That Bind: Law, Marriage and the Reproduction of Patriarchal Relations (London: RKP, 1984); and A. Diduck and F. Kaganas, Family Law, Gender and the State (Oxford: Hart, 1999). For two excellent recent papers which criticise the idea of marriage as the solution to poverty in the context of proposed US welfare reforms, see L. McLain, 'Marriage (E)quality, Marriage Promotion, and Self-Government' and T. L. Brito, "'I'll Take Bachelor Number One!": The Promotion of Marriage as Anti-Poverty Policy', both presented at the workshop, 'Gender and Citizenship', Cornell Law School (19-20 April 2002).

65 Fineman, ibid, 102.

66 See Davis et al, above note 62 at $\mathrm{v}$. 
all come under attack.67 This paper's challenge to the ethical basis for the support obligations of genetic parents introduces a different level of critique, aiming to highlight the unfairness of the general principles underlying the child support legislation. As such, I hope that the analysis of this paper sheds new light on the state's current abdication of what is arguably its most important duty: to meet the basic needs of all its citizens.

67 See for example F. Wasoff and S. Morris, 'The Child Support Act: a Victory for Women?' in H. Jones and J. Millar (eds), The Politics of the Family (Aldershot: Avebury 1996); A. Garnham and E. Knights, Putting the Treasury First: the Truth about Child Support (London: CPAG, 1994); K. Clarke, G. Craig and C. Glendinning, 'Money isn't Everything, Fiscal Policy and Family Policy in the Child Support Act' (1995) 29(1) Social Policy and Administration 26; Davis et al, ibid 212: '[a]ll the available indicators point to the Child Support Agency having become, in effect, an arm of the benefits system'. Recent reports that the CSA has written off d2bn owed by absent parents in its short history, and that another d150m was considered 'possibly uncollectable', have provoked renewed calls for its abolition, The Guardian, 'Child Support Agency Writes Off 2bn' 7 August 2002. 